\title{
Os Indesconstrutíveis da Desconstrução
}

\author{
Gabriela Lafetá
}

\begin{abstract}
Resumo
O presente texto propõe ler a desconstrução quando em seu "movimento de justiça" a decidir sobre a lei. Trata-se, no entanto, de uma operação de justiça para além da instância jurídica e que se encontra em uma singular competência da lei em fazer acontecer o impossível naquilo que ela mesma inscreve como possibilidade. Possibilidade ou, antes, potência que, por Jacques Derrida, é da ordem de uma diferença absoluta que a linguagem instaura quando problematiza sua relação com a lei e com a história.

Mediante um enfrentamento decisivo do texto como ação, a justiça se apresenta como uma lei maior, indesconstrutível, em que, na ação de julgar e decidir por força de lei, não se faz presente, mas participa de uma operação do pensamento que permanece no limiar do conceito. O texto percorre os impasses desse enfrentamento que, ao fim, apresenta a justiça como heteronomia, em que a intrusão do Outro é constituinte à indecidibilidade da lei ao mesmo tempo que constrange uma decisão em seu nome.
\end{abstract}

Palavras-chave: Desconstrução; Justiça; Indesconstrutíveis; Heteronomia.

\begin{abstract}
This text proposes to read the deconstruction when in its "movement of justice" to decide on the law. It is, however, an operation of justice beyond the legal instance and which is in a unique competence of the law in making the impossible happen in what it itself inscribes as a possibility. Possibility or, rather, a power that, by Jacques Derrida, is of the order of an absolute difference that language establishes when it problematizes its relationship with the law and with history.

Through a decisive confrontation of the text as an action, justice presents itself as a larger, unbreakable law, in which, in the action of judging and deciding by force of law, it is not present, but participates in an operation of thought that remains on the threshold of the concept. The text goes through the impasses of this confrontation, which, in the end, presents justice as heteronomy, in which the intrusion of the Other constitutes the undecidability of the law at the same time that constrains a decision in its name.
\end{abstract}

Keywords: Deconstruction; Justice; Indestructible; Heteronomy. 


\section{Introdução}

Este texto quer perguntar diretamente pelo "quê" da desconstrução - o trabalho em filosofia de Jacques Derrida - ao passo em que procura entendê-la como um exercício ético e acerca da ética pautada pela justiça, embora tendo uma forma avessa a qualquer vertente moral que se apressasse a responder pela questão.

A desconstrução, diz Derrida, é um pensamento do impossível, e, no entanto, profundamente rastreador da história. Pois, o que está implicado nesse pensamento é mais do que uma impossibilidade "de fato", mas o perigo da possibilidade, o perigo desta se tornar um conjunto de procedimentos disponíveis baseados em regras e cálculos. O interesse da desconstrução, diz Derrida, é uma certa experiência do impossível como aquilo que vem do impossível e segue em direção a ele quando o pensa, ou seja, que torna o impossível possível nesse seguimento. O que torna possível o impossível segue uma certa valência no trato permanente com o seu alcance, sem, contudo, enclausura-lo num método ou numa doutrina filosófica. Se é possível conhecer a história enquanto se a realiza, bem se sabe que a efetivação de um possível não leva a termo o impossível que carrega, nem mesmo leva a termo o seu acontecimento.

Assim como no caso do perdão, quando a história se fez palco de paradigmas de reconciliação no seio de uma totalidade social e política, ele se recompunha em um "perdão-norma" que, no entanto, não se fizera digno do nome que traz, do impossível que traz pelo dom (no francês, isto é mais claro: par don), permanecendo negado, sob a sombra do possível, no seu caráter indesconstrutível. Como tantas vezes disse Derrida, utilizando a expressão "digno do nome" em seus últimos escritos, será preciso recolocar a discussão sobre o perdão em novos termos para além da reconciliação e do contrato com o possível, ou nada se fará de mais contraditório ao perdão.

O que está implicado, pois, na desconstrução, tal como a tomaremos no presente texto com um respaldo ético ou o de um pensamento sobre a ética, é toda uma concepção de história que será desconstruída, apoiada que está na ideia latente da reconciliação e do contrato com o possível em prol da unidade das nações ou da unificação das diferenças. Desconstrução que, ao contrário, quer encontrar o seu deslimite e a sua impossibilidade em uma forma do alargamento do possível, senão da história mesma, que seja ela a história dos fatos ou da metafísica. É exatamente esse "impossível" na história que interessa a Derrida; e o interessa na medida em que vê nele a lógica do acontecimento contrapondo-se à lógica da história. Assim, se alguma coisa acontece segundo a efetivação de uma 
possibilidade, isto é, enquanto possibilidade na ordem do previsível e do disponível, isto significa que a coisa já estava 'lá' de certo modo inscrita no cálculo da norma ou em alguma teoria historiográfica que revalidasse a sua possibilidade mesma. Porém, se, ao invés, alguma coisa acontece fora desse cálculo e dessa previsão, se essa coisa escapa ao possível esperado - à reconciliação que se espera do perdão, por exemplo -, dali parece vir algo que de fato interessa a Derrida, já que, como ele diz, só o impossível acontece. O acontecimento é, portanto, algo que desfaz um nexo necessário, sendo a ele transversal. Se, de um lado, a possibilidade do nexo é enclausurada por seus limites históricos e conceituais, de outro lado, o impossível é o sem limite de um acontecimento sempre porvir e que se dá em uma esfera interminável de remissões e de decisões.

É assim que Derrida fará a desconstrução de toda uma economia corrente do perdão, de um perdão "tomado nos limites humanos ou antropo-teológicos do arrependimento, da confissão, da expiação, da reconciliação ou da redenção" (DERRIDA, 2004, 545-546) que garante à história, por um conceito reduzido à simples conformidade, o resultado de um cálculo, que seja este pouco ou nada fiel à "fonte". E ele fará a desconstrução dessa 'economia do perdão' para ver saltar do âmbito de sua possibilidade uma problemática ético-política de implicações intermináveis, embora sempre tão atuais, até que uma incalculável potência do impossível entre em cena. Esta potência, sabemos por Derrida, é da ordem de uma diferença absoluta que a linguagem instaura quando problematiza sua relação com a lei e com a história.

Esta potência é a justiça. E é a justiça sob o registo do pensamento da diferença e da alteridade tomadas à ordem da desconstrução que, por sua vez, reinscreve a ordem formal do pensamento. Lembremos o ponto de diferença com Emmanuel Levinas ${ }^{1}$ e aquele de sua proximidade ética com ele, para quem a "diferença absoluta" é inconcebível em termos formais, já que o rosto (marca metafísica da ética) é inapreensível num conceito, já que o absolutamente não-eu que o rosto deflagra e que se impõe como diferença coloca o discurso em relação a outrem (vale dizer, uma relação assimétrica comigo) como o horizonte de uma transcendência do qual sou infinitamente refém. $E$, no entanto, uma negatividade

\footnotetext{
1 Uma ética da desconstrução é assombrada fortemente pela proximidade teórica de Derrida com Emmanuel Levinas, no que toca a um idioma filosófico, a uma resposta à tradição, bem como a uma dívida em duas direções: uma dívida com a herança fenomenológico-ontológica e o que dela permaneceu faltoso em resposta às questões éticas, e uma dívida aliada à 'resposta' mesma, senão à responsabilidade por uma forma do dever como justiça anterior ao direito. Como atestam pontualmente as obras de diferentes momentos do trabalho em filosofia de Jacques Derrida: «Violence et Métaphysique. Essai sur la pensée d'Emmanuel Lévinas » in L'écriture et la différence (1967) e Adieu à Emmanuel Lévinas (1997). A proximidade, no entanto, não diminui o caráter eticamente inaugural da desconstrução. Derrida parte de uma ferida ética levinasiana porém segue por outra via guiada pelo pensamento do todo outro, pela ideia da escritura como promessa, pela noção de rastro, pela arquiescrita de uma força da lei, pela (im)possibilidade do perdão, pela pessoalidade da interlocução e por outras instâncias onde a desconstrução traz à tona a justiça.
} 
os aproxima, Derrida e Levinas, pois se o perdão é inapresentável por sua experiência [do] impossível e por dizer respeito à relação com o outro que é absolutamente outro e, ainda, para Levinas, presença de um rosto para além da forma, o perdão não se generaliza num conceito nem na economia de uma lei tampouco em um princípio normativo. E, ainda assim e por outro lado, Derrida o coloca à ordem formal da linguagem mediante uma violência originária a que a linguagem se expõe quando se expõe ao perjúrio e à traição ao pensar-se a si mesma. Ainda assim deve faze-lo por uma necessidade que é também a necessidade de pensar, bem como a necessidade da própria afirmação incondicional do perdão, ou, caso contrário, encerrar-se-á na possibilidade ou na impossibilidade históricas das ocorrências do mundo como projeto triunfante ou frustrado de reconciliação e reconhecimento de uma totalidade.

\section{Jankélévitch e o perdão}

A ética da desconstrução não acontece apenas por uma fricção com Levinas, como vimos rasgar uma análise que espreita as pessoas morais do discurso ("eu", "outro", "todo outro"), mas é também com respeito ao perdão que se pensa impossível que Derrida abrirá as cenas ética e histórica na discussão com o filósofo francês Vladimir Jankélévitch (L'imprescriptible, 1971) exatamente pela excepcionalidade do perdoar.

É nos debates ocorridos na França em 1964 sobre a imprescritibilidade dos crimes nazistas contra a humanidade que Derrida responde a Jankélévitch acerca de, um lado, a história do perdão pensada como história da reconciliação e, de outro lado, a explosão assertiva de Jankélévitch: "o perdão morreu nos campos de morte", isto é, o perdão tornou-se impossível pelo argumento de que nenhuma punição proporcional pode ser encontrada ao que se apresenta com a Shoah enquanto crime imperdoável e imprescritível. Segundo Duque-Estrada, que acompanhamos na explicitação do argumento, "é toda uma economia metafísica do perdão que entra, então, em colapso" (DUQUE-ESTRADA, 2008, 33). E entra em colapso, ele ressalva, a partir dessa economia mesma, já que Jankélévitch continuaria inserido numa tradição metafísica, religiosa e jurídico-política do perdão como reconciliação e restauração de uma unidade perdida que, com a Shoah, não poderá se ver reconstituído.

Acompanhemos o pensamento de Jankélévitch. Não haveria mais quem perdoa nem a quem perdoar por um crime imperdoável, logo o perdão não encontra mais lugar no mundo, nem no nível individual, interpessoal, nem a nível 
social. Pois houve um crime da humanidade contra ela mesma que ultrapassou os limites do humano ou de uma instância de dignidade reconhecível a que chamamos 'humana' e, portanto, se tal crime não é mais humano, se é inumano precisamente no sentido de quebra com uma dignidade inalienável, tal cenário não comporta aplicação alguma que se reconheça humana, seja ela a punição, a absolvição, a redenção, a reconciliação ou o perdão.

Não se pode punir o criminoso com uma punição proporcional ao seu crime: pois, diante do infinito, todas as grandezas finitas tendem a se igualar; de modo que o castigo torna-se algo quase que indiferente; o que aconteceu é literalmente inexpiável. Já não se sabe mais a quem se dirigir, nem a quem acusar. (DERRIDA, 2004a, 546)

Daí para frente, para as novas gerações, todo perdão será mentiroso, terá o intuito de algum proveito ou será "uma terapêutica do esquecimento" na passagem, então inautêntica, do tempo. É como se Jankélévitch fosse tomado por uma consciência da disfunção do perdão após a Shoah e da sua forçada degradação face a si mesmo - o perdão - quando vier exercer apenas o trabalho ilusório de uma autorreparação. Dessa forma, a história continua porque deve continuar, mas no espaço de um horizonte que assimilou o mal e assiste a funesta cena de um perdão que trabalha em seu próprio luto. Assim é lida, por Jankélévitch, a impossibilidade do perdão.

O impossível [do] perdão a que Derrida chama ao discurso, à desconstrução, é obviamente de outra ordem daquele de Jankélévitch, embora the interesse deste a recusa de um perdão que só terá como fruto a continuidade da história. A decisão de Derrida, ou a sua in-decisão que é como lemos a decidibilidade limiar da desconstrução, segue a seguinte operação: Não posso, "eu, Derrida", conceder o perdão ao não-perdão de Jankélévitch, tampouco negá-lo. Isto porque o perdão é, de um lado, condicionado ao pedido de perdão daquele que faz algo a ser perdoado, e nesse sentido, não é claro quem deve faze-lo, isto é, quem é o algoz e quem é a vítima de um perdão anunciado (Derrida ou Jankélécitch) - eis o performativo de uma condicionalidade mais ampla ${ }^{2}$ e talvez mais complexa do perdão, como atestaram Hannah Arendt em Eichmann em Jerusalém (1963) e a obra documental e literária de Primo Levi É isso um homem? (1947). De outro lado, o perdão está suspenso sob a luz (que é sempre luz contra luz) de uma economia do dom, ou melhor, do incondicional do dom em que uma espécie de resposta a Jankélévitch coaduna ao mesmo tempo em que impossibilita uma decisão definitiva

\footnotetext{
2 Como mostra Rogozinski, Derrida se utilizara relativamente pouco do termo e do contexto da Shoah em seus escritos. Ele a menciona nas seguintes ocasiões: Em Schibboleth: pour Paul Celan (1986), p. 83; em uma outra ocasião em meditação sobre a poesia de Celan; em Fichus (2002), a partir de Adorno, em um diálogo com Lyotard. Ver ROGOZINSKI, J. Faire part, 2005, p. 32.
} 
em seu nome: quando o perdão está a serviço de uma finalidade qualquer redenção, reconciliação, prescrição, luto -, ele não é puro; o perdão deveria permanecer excepcional ou não permanecer, deveria colocar à prova o impossível ou nada possibilitar, deveria interromper o curso dos acontecimentos para além de toda sanção calculável ou apenas demorar na aporia de que "só se perdoa o imperdoável, pois o perdoável já está perdoado" à letra e no nexo estabelecido. 0 perdão não tem pois, respondendo a Jankélévitch, qualquer relação de complementariedade com a punição (DERRIDA, 2003c, 265), sendo alheio ao espaço jurídico e lógico estrito. É por uma exigência de vigilância às racionalidades de uma unidade conciliadora e paralisadora, exigência própria à desconstrução, que Derrida retém e transforma o argumento do perdão impossível de Jankélévitch.

Embora a economia do perdão por uma lógica da reconciliação e o seu desmonte pela desconstrução que deflagra o perdão im-possível se estendam mediante um trabalho exaustivo de remissão conceitual e histórica (por vezes, filológica) em torno da 'palavra', é ainda do perdão impossível que fala Derrida; não para dizer de "uma simples contradição lógica", tal como diz Caputo, mas pelo acontecimento que se dá quando nos perguntamos "como foi possível ir onde não podemos ir" (CAPUTO, 2002, 47). Ali, onde a história do perdão parece chegar a seu fim, tão bem denunciado por Jankélévitch, onde, com efeito, uma dada potência do impossível requer implodir o conceito em sua raiz histórica, é justo onde uma outra potência para a qual a possibilidade do perdão tem lugar e começo, segundo Derrida, ali mesmo no fim da história do perdão onde o perdão mesmo parece terminar, é que começa a história como história do perdão. (DERRIDA, 2004a, 547)

\section{Mandela e a justiça}

"Admirável Mandela. Ponto sem exclamação", e, ademais a pergunta, "como se pode ser Mandela?" (DERRIDA, 2003a, 69). É como Derrida começa o seu texto Admiration de Nelson Mandela ou Les lois de la réflexion, publicado no segundo volume de Psyché. Afirmação e interrogação anunciam uma dupla admiração pela pessoa Nelson Mandela - "o homem mais livre do mundo" (DERRIDA, 2003a, 89) -, engajado em toda a sua pessoa no combate ao Apartheid na África do Sul e na restituição à situação de lei "digna desse nome"; e admiração por aquilo que, de Mandela, Derrida herda acerca das leis da reflexão, ou, como nos lembra Badleh (2015, 209-212), admiração por aquilo que Mandela pensou e admirou da lei - o que uma ação política pode conter e testemunhar do im- 
possível, o que ela pode fazer para criar a justiça e criar um futuro, como deveria ser um homem livre e como um homem livre só é livre se todo-outro homem é livre.

Derrida soube ver nos atos de violência e de não-violência de Mandela uma linha de reflexão que levasse em conta os paradoxos especulativos na experiência histórica com a lei; e, paralelo a isso, a experiência im-possível da lei fez-se ver num processo infinito de renegociação da lei e com ela, em que toda a violência institucional devesse ser pensada. Derrida ressalta, com Mandela, que todas as democracias constitucionais provêm de um golpe de força que está na base de toda lei (tese defendida e desenvolvida por Derrida em um texto magistral que viria a ser publicado oito anos depois com o nome Force de loi, 1994), isto é, que todas as democracias constitucionais provêm de um ato violento que, ao mesmo tempo em que pressupõe a lei enquanto a reproduz, instaura a unidade de uma nação après coup.

Mandela sabia disso: é uma minoria que faz e promulga todo governo democrático e toda Constituição; é o ato mesmo de um contrato que, assinado pela minoria que se faz representativa, supõe o povo inteiro e, por isso, legitima a assinatura em tal ato pela entidade da nação. Derrida o equaciona da seguinte forma: a legitimidade da lei é fundada pela ilegitimidade de uma assinatura e de assinantes que, num gesto performativo, efetiva a lei, e que só passa a ser lei porque fora previamente legalizada por uma assinatura, ou seja, tem-se na base da questão uma assinatura que toma sua legalidade de uma lei prévia, e essa lei prévia só se confirma após a assinatura.

O que aconteceu na África do Sul entre os anos 1948-1994, com o nome de apartheid, não nos é tão estrangeiro. Foi quando uma minoria branca, mediante um golpe de força de manobra eleitoral, assinou os desígnios sociais e políticos de uma nação sob um regime de segregação racial. Mesmo sob a égide de um regime democrático algumas condições propiciaram a manutenção de um novo status quo político que pôde se fazer valer de um esquecimento, com que ninguém se lembre da violência performativa originária, dentre as quais podem estar as seguintes condições: a primeira, quando parte do povo participa do governo (digamos, um terço do eleitorado); a segunda, quando uma outra minoria popular se alia ao novo regime (então, dois terços do eleitorado); e, finalmente, quando, sob a força máxima de um apelo ao genocídio ou de uma quase-exterminação, a minoria empossada (um terço do eleitorado) exerce, triunfante (ao número e ao alcance dos dois terços), sua força de lei. No entanto, o que aconteceu na África do Sul naqueles anos foi que o gesto de violência de uma expressa minoria branca, que promulgou para si todas as riquezas da nação, foi excessivo e, ao mesmo tempo, 
impotente, insuficiente para assegurar a estabilidade do contrato assinado. Foi então que, evidenciado em sua contradição e tendo como consequência o fato de que o seu golpe de força não pôde se fazer esquecer, o golpe político torna-se, retroativamente, um mau golpe de força ou aquele de uma força fracassada de lei.

Foi contra esse mau golpe de força da minoria branca que Mandela se opôs, evidenciando sua falha enquanto estabelecia um contra-golpe de força através do Congresso Nacional Africano (CNA) e da Carta da Liberdade. O que vai nos interessar é de que forma Mandela instituiu dois golpes de força na significância da lei, sem opor à lei dos brancos outra lei, mas fazendo resgatar da lei dos brancos, daquela mesma que fora assinada democraticamente em seu país, a sua dignidade de lei exatamente pelo seu golpe de força.

Enquanto o regime em curso representava apenas os brancos (contra a lei que eles mesmos assinaram, baseada na Declaração Universal dos Direitos Humanos), o CNA se levanta na defesa da lei dando a ver o que não estava visível na sua aplicação: "que a África do Sul pertence a todos os que nela vivem, negros e brancos, e que nenhum governo pode afirmar autoridade a menos que se baseie na vontade de todos os povos", diz a Carta da Liberdade. Ao lançar os olhos e testemunhar, pela lei no seu caráter de lei ou de Lei das leis, o ato fundador da lei ou a constitucionalidade da Constituição (a lei magna que uma minoria branca assina e não cessa de trair), Mandela opõe à entidade étnico-nacional que só inclui os brancos numa situação nacional de direito uma outra entidade étnico-nacional que inclua todo o povo, inclusive os brancos.

O "sim" à democracia, o "sim" à África do Sul que preconizava a lei magna, ganha força (de lei), mas, nesta feita, o "sim" deve ser digno de um "sim a um povo inteiro" inclusive a todos os grupos nacionais. Que a decisão política do CNA se baseie em um corte geográfico e demográfico de um momento e um lugar determinados na história da democracia no Ocidente e que reinstitui uma dada universalidade em nome da lei, qual seja, a lei fundamental prévia que reconhece quem é "o povo inteiro de uma nação" - todos que vivem nela - então desobrigada pela colonização branca, a Carta da Liberdade reinscreve a decisão no ato de fundação da lei, por seu próprio discurso e em solo sul-africano para uma sociedade sul-africana que é anterior à chegada do homem branco. O gesto performativo do golpe de força é deliberadamente re-atuado, e reformula o ato constativo que segue a lógica do golpe de força da Constituição dos brancos, porém radicalizando seus princípios mesmos de democracia e de lei, sendo-lhe absolutamente fiel por uma infidelidade aos contratantes. Está aí algo muito próximo ao gesto da desconstrução que Derrida tem para com a tradição filosófica. Na África do Sul, ele 
foi golpe de força democrática por meio da ação política do CNA e na presença de uma reflexão ético-política a partir da reflexão de um homem 'livre'.

Mas, ainda não chegamos onde é preciso chegar com a exemplaridade histórica da África do Sul nos anos oitenta e noventa do século passado, e o exemplo singular na pessoa de Nelson Mandela. E esse lugar é a justiça. O que é a justiça, vale a pergunta: a lei do direito ou algo fora-da-lei do direito? Dirá Derrida que Mandela responde às duas coisas, em nome de uma Lei maior.

Mandela se apresentou diante da lei para convoca-la (e não para espera-la comparecer como em resposta, e como Kafka a espera no conto Diante da lei, mas), para fazê-la acontecer. Lembremos que, segunda Derrida, só o impossível acontece; e quando Mandela comparece diante da lei para fazê-la acontecer, ele não se apresenta a serviço do direito que então a subverte, mas responde a uma Lei maior presente na lei do direito embora seguindo o "movimento da justiça" (DERRIDA, 2003a, 79), e é na experiência do impossível que está a justiça. Esse movimento da justiça não aponta para uma justiça que será, um dia, uma realidade após um determinado decurso da lei. E é por isso que Derrida diz em duas ocasiões diferentes e não distantes entre si que "a desconstrução é a justiça" (Força de lei) e depois que "a desconstrução é a experiência do impossível" ("Como se fosse possível, "within such limits"..."), isto é, que a justiça tem lugar a cada vez que a desconstrução está em curso pois, nela, está a prática mesma da justiça. Para além do ato político na convocatória de um Congresso, para além mesmo da dimensão política da lei que Badleh entrevê como a dimensão mesma da desconstrução quando em "movimento de justiça" decide sobre a lei, é, pois, de uma operação de justiça para além da instância jurídica que se encontra uma singular competência da lei em fazer acontecer o impossível naquilo que ela mesma inscreve como possibilidade.

A reflexão da lei, o comparecimento diante da lei e o comparecimento dessa lei diante da lei superior é o que Derrida chama "o movimento da justiça". (...) A admiração da lei por Mandela é, por assim dizer, semelhante à prática da desconstrução. (BADLEH, 2015, 213-214)

Resta-nos saber quê lei é a Lei maior que se apresenta no impossível, qual a sua natureza e em que ela promove tanto a prática da justiça como a prática da desconstrução. Prática da desconstrução que, tal como pensamos, diz absolutamente respeito ao alcance ético da desconstrução. (Ética: a "velha palavra" que se tenta mudar ou, por vezes, emudecer o sentido, senão para fazê-la, para torna-la, por seu sentido, o quão mais digna, é o que dirá Derrida em, ao menos, 
dois textos ${ }^{3}$; mesmo quando ele nega que a desconstrução tenha algum compromisso com uma "ética") A Lei maior que atravessa o espaço da lei de direito não está exatamente em um texto e está em todo texto, embora a justiça na lei não se confunda com a justiça da lei. Os testemunhos exemplares (e não seriam eles impossíveis e testemunhos da ética?), dirá Derrida (DERRIDA, 2003a, 88), são aqueles que, dando a pensar a lei, não respeitam as leis e, não as respeitando, se veem divididos entre uma desconstrução à ordem da justiça e uma justiça que se apresenta indesconstrutível.

\section{A justiça entre a desconstrução e os indesconstrutíveis}

Quando Derrida, em não poucas vezes, deixa-se escrever sobre o possível (como em "Como se fosse possível, "within such limits"...", 2001), ele "joga" com uma estrutura lógica (no citado texto, em oito aforísticas), utilizando-se de um gesto performativo tal como o fez em resposta a John Searle na Reply em « Limited Inc. » (1990) $)^{4}$ : responder ao que parece um simples jogo verbal, qual seja, que 'o possível é o impossível' (do tipo $S$ é $P$ ) arrisca-se ao perjúrio na resposta se não se assume, sob a marca performativa de uma "insuficiente suficiência", um absoluto, um impossível ou, como assumiremos o termo, nós leitores por entre a justiça e a desconstrução, um "indesconstrutível". Levando-o precisamente a termo, Derrida diz ainda, tal como fizemos recuperar o diálogo com Jankélévitch: se o perdão é impossível na qualidade de um gesto sempre gratuito e incalculável, não se perdoa jamais "em conformidade com um dever" ou "por dever" segundo a máxima kantiana, mas perdoa-se, se se perdoa, para além de qualquer imperativo categórico e a despeito de um pedido ou de uma confissão nos trâmites da reconciliação. Perdoa-se, se se perdoa, na prática ostensiva e na força de lei do perdão. Ou o perdão é incondicional, ou ele não é perdão.

3 DERRIDA, J. Séminaire La Bête et le Souverain (2001-2002), 2008, p. 307. [Uma proposta que tenta mudar o sentido (...), fazer mudar o sentido, mantendo a velha palavra ou pretendendo render a ela o seu sentido o mais digno.] Também em Cosmopolites de tous le pays, encore um effot! (Galilée, 1997c), Derrida usa a expressão "sous le vieux mot" para propor a palavra villes-refuges no encalço da "velha palavra" embora num "conceito inédito" de hospitalité.

$4 \quad$ O texto-fonte de uma querela com Searle que teria culminado na Reply é Sec (apelidado por Derrida a partir de Signature, événement, contexte, 1972 in Limited Inc., 1990). Sec foi, frequentemente, lido como um projeto de desmantelamento da teoria dos atos de linguagem, por Derrida. No entanto, a Reply contradiz essa leitura, mostrando que a intenção de Derrida, na sua própria leitura da obra de Austin, era pensar o alargamento do possível, ou melhor, do campo do valor da ação em todos os atos de linguagem. E que as premissas para esse alargamento, num trabalho de operação textual próprio ao que é a desconstrução, estavam todas elas na obra de Austin, sem que ele as tivesse levado a termo de um alargamento proporcional ao projeto mesmo de sua obra. De modo que a iterabilidade essencial do signo (o fato de que todo signo adquire sua identidade de sua repetição iterável), isto é, nisso que todo signo é destituído de sentido próprio, fixo no real, posto ser constituído de repetição e alteração em contextos distintos, neste fato negado pelos teóricos dos atos de linguagem, de modo, pois, que, sendo iterável, é a ficção uma possibilidade estrutural do signo. E que as oposições metafísicas bem como a "seriedade" que quis dotar Austin a todo ato performativo bem sucedido não fogem à estrutura ficcional e iterável do signo, já que todo signo é, para ser sucedido e como bem alude Austin, sempre uma citação ou uma repetição inventiva. 
Embora pudéssemos dizer com Platão, ainda no seio de um pensamento de transcendentais, de "absolutos" em Derrida, ou como ele prefere de "impossíveis" ou "incondicionais", uma ética da desconstrução não guarda um ideal. Não é por ele que a incondicionalidade vem ao discurso sob a égide de um indesconstrutível na desconstrução. Não há uma ideia absolutamente inteligível que ditasse universalmente as regras do argumento; não há eidos, não há lei universal, assim como não há princípio ou um 'possível' a se cumprir (DERRIDA, 2003b, 62). Não se pode esquecer que Derrida está ligado a uma certa crítica contemporânea, e que ele próprio soube tão bem nomear, da metafísica da presença. Não há metafísica que autorize a desconstrução, pois não há a presença para além da materialidade da escrita. E, no entanto, estamos às voltas com parâmetros transcendentais que não são destituídos de infinitos impasses à razão, e, muito embora não sejam eles ideias ou princípios metafísicos, eles nos fazem ver, como de fato um parâmetro o faz, o quão distantes estamos de uma certa idealidade dos conceitos que se impõe por um padrão lógico, não transcendental. O dizer à distância de um conceito ideal, bem como de sua qualificação para uma possível lei universal do direito, não é levado mais em conta do que um cálculo performativo da própria distância que intencionasse esse dizer. Embora pudéssemos dizer, então, de quase-conceitos quase-transcendentais que deixariam o pensamento em infinita análise enquanto vislumbrasse sempre uma impossibilidade, há um elemento indesconstrutível na desconstrução que Derrida identificou prontamente com a justiça.

Não tem o "absoluto", para Derrida (e para usarmos um dos termos acima citados ao "indesconstrutível" na desconstrução), o sentido que traz a Ideia platônica de uma associação, ou participação em uma ideia maior - no Bem e no eterno -; também não herda de Kant a qualificação para o reconhecimento de uma lei universal, nem de Hegel a possibilidade, conquanto a sua plasticidade, de um saber absoluto. A justiça, assim como o perdão e o dom são im-possíveis, ou indesconstrutíveis, não em função de uma participação ideal, inteligível e sintética a uma noção mestra, mas de uma quase-transcendentalidade que permanece no limiar do conceito, suspenso por um ultrapassamento, pela possibilidade de um ultrapassamento que, como tal, é impossível quando jogado na operação da desconstrução. O Bem é tomado à desconstrução por Derrida; o dom, por exemplo, não.

Não tem, ainda, o "impossível" o sentido do irrealizável, mas da aporia que toma o pensamento quando absolutamente unido à linguagem e ao tempo; diz-se da linguagem que se demora, que ganha tempo e distância para decidir e, se decide e quando decide, é ao tempo de se medir a différance, ao tempo em que se dirige a ela os olhos como parâmetro, sentinela. Erra quem afirma ser a 
indecidibilidade derridiana uma paralisia na ação de julgar; ao contrário, ela é a prática mesma do julgamento levado a seus impasses e a seus limiares decidindo por uma temporária suspensão da escolha entre alternativas. A aporia, "entre alternativas", designa o trabalho da desconstrução.

Quando, em seus escritos de juventude, Derrida sublinhava a ambiguidade resoluta dos conceitos filosóficos, sua determinidade "desde fora", quando não no texto, contra o texto, ele quis igualmente mostrar que o signo é a instância determinante de todas as oposições constituintes da "metafísica da presença" infinito/finito, alma/corpo, inteligível/sensível, natureza/lei, origem/artifício etc. - e, portanto, a sua desconstrução lhe pareceu urgente. Ao suspender a escolha por um dos signos e inscrever no discurso filosófico a insubordinação de um significado a outro pela diferença [différance], a obra de Derrida culmina em um certo impasse do político, é o que escreve Critchley em The Ethics of Deconstruction, e, no entanto, ela inscreve, decisivamente, o questionamento ético sobre a justiça. Ao suspender a escolha "por direito" numa democracia de direito, a desconstrução inscreve a aporia na experiência com a linguagem por uma negociação ininterrupta. Trata-se, pois, de uma aporia saída da relação ética com o outro, que veremos logo adiante por uma relação com a ética em Emmanuel Levinas mas que, por ora, o próprio Critchley faria a ressalva por "uma política da diferença ética" (CRITCHLEY, 1999, 221).

\begin{abstract}
Um questionamento desconstrutivo que começa, como foi o caso, por desestabilizar, complicar ou lembrar em seus paradoxos valores como aqueles do próprio e da propriedade em todos os seus registros, aquele do sujeito, e então aquele do sujeito responsável, do sujeito do direito e do sujeito da moral, da pessoa jurídica ou moral, da intencionalidade etc. (...) um tal questionamento desconstrutivo é, do começo ao fim, um questionamento sobre o direito e sobre a justiça. (DERRIDA, 1994, 22)
\end{abstract}

O que é preciso estabelecer na desconstrução unida à ação de julgar é uma relação entre a aporia e a decisão. Nisso que nenhuma decisão pode ser plenamente justa e nisso que a justiça excede, sempre e a cada caso, as leis do direito, a justiça, para Derrida, é a relação com o outro em que se poderia suspender o direito. Tal como um juiz que, antes do que seria aplicar uma regra, suspende o direito ao sancionar uma lei no ato de interpretação "para dever a cada caso reinventa-la, rejustifica-la" (DERRIDA, 1994, 51). Vimos com a história de Mandela que uma força de lei é exigida da lei enquanto só pode ser exercida diante da lei, ou melhor, diante de uma lei que não acontece e que jamais terá lugar, que jamais ocupará o lugar do direito (no caso da África do Sul, a força de lei da igualdade de direitos a todos indistintamente só pôde ser exercida e chamada à instituição e à decisão como um grito antes do que como lei, diante e par contre a 
lei de direito). A justiça é essa lei, ou essa ação de julgar por uma força de lei, que não pode se fazer presente, mas que ainda assim, e só assim, é justa. Usar a força da lei contra a lei não é sair da justiça, mas é, antes, traze-la onde ela não chega. É mostrar a insuficiência da lei, que é insuficiência $e$ infinitude de todo texto, de tudo o que é dito diante de uma justiça inalcançável e por alcançar.

Estamos, pois, diante de uma impossibilidade, sob o traço da justiça, de fazer possível a justiça tal como o é a de fazer possível uma ética do perdão ou do dom, ou mesmo impossível pela entrada do terceiro na relação com o Outro ("o passado da relação com o outro assombrando o presente da relação com o terceiro" BADLEH, 2015, 253); e, não nos deixemos dispersar, temos aí uma possibilidade: a possibilidade de uma ética im-possível. A justiça é, nesse sentido, uma questão aporética por excelência que acontece na prática da desconstrução. Impossível que é, a justiça abre a possibilidade de uma ética que, vigilante ao alcance de uma intervenção prática, sabe que o todo-outro está sempre por vir e que, de sua vinda, impera a condição, talvez única como condição, da menor violência possível.

Sabemos, toda decisão que se pretenda instituir algo designa uma violência na medida em que toda instituição consiste em uma decisão que designa, a seu tempo, uma lógica paradoxal; qual seja, a de que a autoridade da lei, enquanto força de lei, é ela própria a lei de direito - suspenção e instituição da lei. Derrida toma emprestada essa economia da lei e, por ela, a distinção entre justiça e direito, de Montaigne, da ideia de um "fundamento místico da autoridade" que denuncia no começo de toda lei uma força sem fundamento de fato, seja a lei de direito seja a lei que suspende o direito. Trata-se de uma espécie de golpe de força que é fundador da lei sem ser seu fundamento; como se um suplemento de ficcionalidade, não de natureza ou qualquer forma da arché, fundasse a verdade na justiça. O que não quer dizer que se deslegitima a lei ao funda-la em um golpe de força ou em uma violência performativa, tampouco que se torne infundado o fato de que a lei, como fruto de uma decisão pela justiça, jamais terá lugar. A lei e a autoridade que ela traz consigo não são nem justas nem injustas, nem legais nem ilegais em seu momento fundador. Elas não trazem em sua origem uma transcendentalidade ou uma ideia jusnaturalista que lhes concedessem critérios de razão ou intuição prévias. Não havendo transcendentais, a decisão pela lei e pela justiça só pode se dar a partir da desconstrução da lei e de suas condições metafísicas e políticas ("violência contra violência. Economia da violência" DERRIDA, 2011, 165). "O direito é essencialmente desconstrutível"; já a justiça é seu elemento indesconstrutível (DERRIDA, 1994, 34).

Retemos algo a esse respeito já de nosso filósofo: não se trata de derivar a ética de uma justiça aplicável ao direito, à política ou à filosofia; não se trata de 
querer, sob as vias de um método ou da formalização de uma axiologia que se estruturasse em um sistema filosófico, traduzir a ética em "valores que conformariam uma ação desconstrutiva". A desconstrução que se dá ao campo da escrita (da escritura ou no "grito" instituído diante da lei) não é a busca da verdade, é a busca da justiça. E esta não tem o mesmo estatuto ético-ontológico daquela. A desconstrução é o indesconstrutível da justiça, eis o que nos impõe ainda uma explicitação em seu âmbito de questão e de prática filosóficas.

\section{No coração de um quiasma}

Vimos pensando e traçando na primeira parte desse texto as vias de contato no "coração de um quiasma"5 entre dois filósofos do impossível: Jacques Derrida, por um pensamento do im-possível e da incondicionalidade entregues à desconstrução, como vimos, a partir do apagamento sígnico do conceito rumo ao sulcamento de um rastro lisível em que se vê a irrupção do "absolutamente outro" na inscrição de uma différance; e Emmanuel Levinas, por um pensamento do infinito "inscrito" no rosto do outro homem a marcar uma intriga ética diante da qual uma separação metafísica se dá ao discurso e ao mundo entre o Mesmo e o Outro. Falta a nós a incursão sobre o pensamento levinasiano à apresentação mais concisa dos indesconstrutíveis na desconstrução.

Se a escrita sem signo da desconstrução pode se apresentar ao lado do dizer levinasiano para além do estatuto ético-ontológico da verdade, o seu gesto é explicitado como um dizer sem Dito, ou um dizer que leva o Dito à aporia quando resgata o elemento indecidível da justiça, à luz do texto. No coração desse quiasma DerridaXLevinas, a intrusão do Outro é constituinte à indecidibilidade, ao mesmo tempo que constrange a uma decisão em seu nome.

A desconstrução recupera, com a ética levinasiana, uma justiça que não segue os padrões do Dito (do conceito, do "imperativo categórico" ou de uma ontoética que Derrida quer desconstruir), mas que pode ser entendida à maneira de um resgaste outro da decisão. Trata-se de um desinteressamento (termo levinasiano) que o Outro faz acionar quando salva no Dito o dizer traído pelo verdadeiro. Deslocar o Dito do seu centro estrutural de sentido faz-se pensar a possibilidade de uma intrusão por vir e sempre vindo de um dizer. Desse modo, o trabalho da desconstrução consiste em mostrar que as contradições e as cegas aporias do Dito são constitutivas do discurso filosófico instituído por sua força de lei, mas que, pela

Que é como Emmanuel Levinas caracterizou a sua relação com o pensamento de Jacques Derrida; e que constitui o tema e parte do título do texto de Fernanda Bernardo, publicado na Revista Filosófica de Coimbra - n. 33 (2008), "Lévinas e Derrida - "um contacto no coração de um quiasma". 
violência e pela fidelidade com que um tal Dito se impõe, torna-se preciso rever o que a violência e a fidelidade deixam de impensado. A desconstrução do Dito traz à letra (ou à face do outro homem) um dizer que opera nas suas contradições; aquelas mesmas que a filosofia procura resolver, senão dissolver à luz de sua coerência metafísica e na sua irredutível decisão legisladora pelo sentido e às fronteiras do sentido.

Ora, toda escritura (que se deixa traduzir como a escrita que, por quaisquer meios legíveis, lê-se pela techné, pelo arranjo, pelo espaçamento que do signo abre-se ao rastro, e, só por isso teima em ser escritura e manter o radical tura do qual Ihe transpareça a técnica fundante), assim como toda instituição, legisla suas fronteiras mediante uma decisão; e esta decisão diz de uma inscrição de lei, de força de lei e de negociação com a lei frente às presenças intrusivas do empírico no transcendental, do metafórico no metafísico ou, finalmente, de um elemento quasetranscendental no categorial. Ir a uma outra coisa que não à forma segura do sentido e do Dito e às possibilidades sempre levadas a seu término pelo conceito, ou ainda, passar a uma outra coisa que não aos fenômenos e o que eles realizam intencionalmente por suas fronteiras mesmas, designa um lugar à desconstrução que se traduz na investida sintática, performática, remissiva, dêitica e interruptiva de uma dimensão propriamente ética do pensamento.

A espera sem visada de esperado, a espera do inexpectável
[I'attente de l'inattendable], impõe uma dupla imposição, porque ela
não é verdadeiramente a espera, simples e previdente, do que
provavelmente acontecerá. (...) O reino que o Messias instaura não
é um reino entre os reinos das nações, nem uma história, nem um
espaço ou um tempo «decalcado sobre o espaço». É um reino da
justiça sem fronteiras. (BENSUSSAN, 2013, 317)

Uma certa impossibilidade ou incondicionalidade, que move a desconstrução em sua operacionalidade, articula-se com a justiça sem fronteiras do messiânico que aparece em um certo monolinguismo entre Derrida e Levinas, como diz Gérard Bensussan da espera sem visada. Diz-se de uma messianidade que se inscreve diferentemente em Derrida e em Levinas, muito embora tanto um quanto o outro contribua com importantes interrogações acerca do Messias ao debate filosófico contemporâneo. Enquanto que o messiânico de Levinas assume, com toda a carga interpretativa e remissiva de uma ética radical do Outro, o contra-tempo da religião na diacronia irruptiva pelo rosto; em Derrida, o messiânico é o porvir de uma véspera ab-soluta do tempo que, entre a filosofia "grega" (de Platão a Heidegger, inclusive Levinas) e a religião abraâmica, move o seu pensamento.

Um outro rasga a pretensa pureza, inteireza e lisura do texto de cada um deles e os heterogeniza, fazendo cada um deles falar a mais de uma voz (e, portanto, nunca a uma (só) voz!): é 
atentamente virado para o segredo absoluto deste absolutamente outro, em sua memória, que Jacques Derrida pensou, ele que, lembro-o também, confessou ser sua paixão e seu desejo mais premente dar a ler a interrupção - da atenção a este segredo com a feição do tempo, desta experiência da alteridade ab-soluta brotam todos os seus incondicionais ou todos os seus impossíveis. (BENSUSSAN, 2013, 343)

A estrutura da enunciação levinasiana é levada a termo por Derrida: é o "sim originário" da desconstrução atenta ao apelo do outro que é o apelo da diferença absoluta. O "sim" da heterogeneidade frente à separação que isolaria os termos da relação é este "sim" ao não antecipável pelo Dito que expropria o sujeito [em francês é sugestivo, pois o sujet é também tema, assunto] e que é ouvido a mais de uma voz, por contraste à 'crítica' que, a cada Dito, uma única voz se imposta. Apesar das diferenças com Levinas, que poderíamos começar a apontar pelas perguntas "quem é o outro na ética levinasiana?", imediatamente ao lado de "quem é o outro irruptivo na desconstrução?", trata-se sempre da vinda do outro que, em todo caso, é todo e qualquer outro [tout autre est tout autre] como advento da justiça.

Contudo, não nos parece encerrar aí, na entrada do Outro à cena do mundo e da escrita, o argumento em favor do qual a desconstrução é a ética ao incorporar à letra um indesconstrutível. É preciso que a desconstrução como pensamento do impossível se volte à transcendentalidade como "lei maior", ou como prefere Derrida, ao quase-transcendental da justiça. É preciso situar essa lei maior que é a justiça em dois espaços distintos da reflexão: o im-possível que trouxemos de Derrida no diálogo com Jankélévitch; e a afirmação de Derrida de que "não há nada fora do texto".

É então que, como a justiça não se apresenta enquanto conceito, filosófico ou jurídico, podendo mesmo sugerir que da desconstrução nada fica senão um niilismo ampliado, é então que a justiça se apresenta diante da lei por um movimento retórico. Diz-se de uma retórica como aquela que empreende Mandela no CNA e com a Carta da liberdade nas mãos, imbuído que estava de uma reflexão a postos de um enfrentamento decisivo do texto como ação. Ora, esse enfrentamento, longe de separar texto e ação, desenha o horizonte do qual o Outro, o acontecimento ou a chegança do que está por vir desde uma véspera absoluta do tempo, é já texto, escritura. "O conceito exige sempre frases, discursos, trabalho e processo: texto, numa palavra" (DERRIDA, 2004b, 270). E é no texto que a "desconstrução é a justiça", nisso que ela põe à luz a não-inadequação a si do presente e a intensificação máxima de uma transformação em curso (DERRIDA, 1994, 24). 
Esse duplo enfrentamento no texto - entre lei e ação - é um enfrentamento tanto da retórica quanto do conceito, ou seja, tanto na promessa de um futuro, de um porvir absoluto que é já escritura e, no entanto, não pode ser lido em um Dito, quanto na dívida com um passado (conceitual) que se deixa ser lido em seu apagamento, isto é, deixa-se ler o rastro - deixa ler na promessa, por sua força de lei, o apagamento do perjúrio que ela contém. Essa promessa e essa dívida que se dão na dimensão performativa da linguagem são legíveis na lei do texto, que é também a lei da repetição e da ação como repetição. E então é onde a desconstrução designa, no ato iterável da linguagem, a singularidade do acontecimento do outro. Ao mesmo tempo em que nos dá todas as razões para pensar que dessa singularidade e da repetição que a torna sempre singular a cada vez de sua aparição, está o trabalho da desconstrução na prática da justiça.

Estamos, aqui, tomando a obra derridiana obviamente por um traçado contínuo, desde seus textos ditos "políticos" nos últimos anos de escrita, até a obra mais "conceitual" de Derrida de antes dos anos 90. Sem giros, descontinuidades ou implicações políticas, ao que se a tomaria uma corrente de leitores da obra derridiana que procura salvar "um Derrida" condenando o "outro Derrida", quer dizer, o Derrida de seus primeiros textos que teria se empenhado a fazer uma análise da linguagem ou acerca de uma estética literária sem nenhuma contribuição à vida política numa sociedade liberal (assim se resume a ácida crítica de Richard Rorty a Derrida), ou, ao invés deste, o Derrida engajado em assuntos eminentemente político-partidários de uma sociedade liberal, tais como o feminismo, a luta pelos direitos dos animais ou um certo "marxismo liberal". Entendemos que nenhum desses dois Derrida dão conta de sua obra, se não fosse demasiado dizê-los caricatos; e que o ato performativo da linguagem que marcará o enfrentamento ético-retórico com a lei e com a ação no texto é, linha geral, o trabalho da desconstrução.

Ao longo de sua escritura, Derrida resgatou conceitos perdidos da ética, talvez em desuso ou apenas por vezes mencionados à margem da discussão sobre a moralidade, tais como, perdão, dom, hospitalidade, testemunho, fidelidade, dívida..., para repensar a ética de um outro modo. Um outro modo que tome a desconstrução das leis da linguagem metafísica para pensar a justiça que, como força da lei, é indesconstrutível. A justiça, esse quase-transcendental que move o processo do conceito, move ainda o trabalho do texto na desconstrução.

É notável como Derrida nos oferece o objeto de uma questão propriamente transcendental que se toma à letra por um conceito reticente acerca de quem é o outro de que a ética se ocupa, de que Outro ela se refere quando o absolutamente não-eu dado no rosto do outro homem se estende à significação do todo-outro, ou 
do todo-e-qualquer-outro - que tomemos deste o conceito de 'animal' - que vai sendo desvelado a tempo de, talvez em seu momento mais estruturado no Séminaire La Bête et le Souverain, marcar a dinâmica mesma de um curso. Com Deleuze, nesse percurso, é lançada a pergunta no cerne de uma relação entre texto e ação, entre o 'próprio' e o 'possível': "como a besteira [bêtise] é possível?". Se ela não é um próprio da besta, já que esta não pode responder por si (fiemos esta enunciação desde um ponto não desconstruído da desconstrução: uma besta não pode responder por si), a besteira seria uma certa abertura do sentido, que é sempre da ordem do julgar. "O besta" comete, por sua besteira, um lapso, uma falha na atitude de julgar, um gesto "atordoado, desviado, ao mesmo tempo inibido e confuso do julgamento" (DERRIDA, 2008, 245). Não é, pois, algo proposital, uma fatalidade ou um erro ou mesmo um mau julgo que define a besteira, mas um lapso.

Se a besteira é um lapso, ela aparece na dinâmica mesma do pensar como condição ao pensar e está, pois, no coração da filosofia. Bem antes de autodeterminar-se pelo animal, a besteira aparece onde quer que haja um quem soberano (alguém que responda por si) em contraste com um que ou uma área de jurisdição da soberania (DERRIDA, 2008, 248). Ela, a besteira, que apareceria como uma maneira de categorizar o outro pela acusação de uma falta de inteligência ou de um saber ou ainda de um ethos, aparece para Derrida como uma categoria - se é que há a categoria "besteira" - cujo sentido não se deixa determinar. A besteira se recusa a ser uma categoria. Ela é a restância do pensamento que a pensa. A besteira aparece como uma insubordinação do pensamento quando pensa; e se ela está no coração da filosofia, já que reside nas forças que instauram a soberania e regulamentam a besteira, ela aponta para um desvio de olhar àquilo que está sendo ofuscado pela presença do soberano sem que nela se reconheça enquanto tal - "besta". Desde esse outro registo do olhar, a besteira insinua uma justiça ainda retificável, ainda incompleta, um julgo que escapa do legível ainda que esteja como rastro no texto.

Ao trazer à toa uma relação entre o 'próprio' e o 'possível' (o que é próprio à besteira e o que a faz possível?, cujas respostas seriam, respectivamente, o pensamento que pensa e o pensamento que se pensa), é então que volta a pergunta pelo 'possível' da justiça, antes ao que Ihe é próprio. Como ela é possível como im-possível, e como ela é elemento indesconstrutível da desconstrução? Sendo a justiça uma acusação na operação da lei, uma acusação no cerne indecidível da decisão, ou ainda, uma atribuição ou uma categoria excepcional, tal como, antes de Kant, a Idade Média conferira a primeira definição literal do transcendental - qui transcendit omne genus -, é a justiça uma categoria que 
transcende todas as categorias. Dela, diz-se de uma certa experiência em trazer do pensamento o que não se pode apresentar (fazer-se presente) à letra, a não ser como pensamento do impossível para a qual Derrida outorga a categoria excepcional de quase-transcendental.

Dizemos, enfim, do elemento indesconstrutível da desconstrução - a justiça - que faz do pensamento mais do que um mero exercício especulativo ou conceitual, mas que o aproxima de uma transcendência ética mediante uma prática de desvios e enfrentamentos, decisões iteráveis e negociações infinitas. Que ela esteja em um "fora" ou "desde um fora" irruptivo e não antecipável, que a justiça seja uma categoria excepcional ou fundacional do direito e que se forje dentro de um "jogo" de escritura, a promessa da justiça só acontece desde dentro da desconstrução.

Nesse jogo do dentro-fora, lembro-me aqui, com Gérard Bensussan em Les Équivoques de l'Étique (2013), da anedota contada por Diógenes Laércio que põe em cena Diógenes, o Cínico, prestes a pedir esmola a uma estátua e de quem, como conviera a observação de um interlocutor atento a tamanha extravagância, não espera absolutamente por uma resposta: "treino-me para não receber nada", teria explicado Diógenes, o Cínico, ao observador (BENSUSSAN, 2013, 147). Por uma leitura não restritiva à filosofia cínica, mas que, ao fazê-la, percorra a doutrina platônica da anamnese, vemos que o sentido lido e retido na anedota é o de que mesmo aquilo que eu recebo de fora se encontra já e desde sempre em mim, "dentro" de mim, de modo que a única coisa que deve ser feita para eliminar os obstáculos entre eu e a coisa é lembrar claramente. Ou seja, o "choque vindo de fora" que abala o meu ser, de que fala Levinas nos Carnets de Captivité (2009), é de tal maneira amenizado pelo reconhecimento de um 'próprio' a mim ou de um 'já conhecido' por mim, que recebo um choque que não é mais e nem será tampouco um choque mas uma vibração anamnésica que me atravessa do interior; bastandome para tanto, a mim mesmo, recordar a origem mais íntima do meu conhecimento de justiça, que treina por não receber nada de fora.

Ao contrário, se a justiça é a irrupção de uma novidade sempre por vir, se ela é precisamente uma impropriedade nesse porvir, uma precisa inapropriação por vir, ou se ela é o horizonte da promessa desconstruindo-se na sua condição de perjúrio e, só nessa condição, disposta a abrir a mão "a uma estátua" e esperar dela o inesperado, se a desconstrução encontra, pois, seu poder e seu fundamento nesse ser-possível e sempre im-possível ao ser, ela continua a assombrar toda decisão que se quer cálculo e toda justiça que se queira justa. Assim, a justiça abriria mão de uma autonomia (que aceitaríamos sem muito problema como um autopertencimento ou uma legislação de si a partir de si) e estaria, ao invés, dada 
a resignificar o filosofema da decisão e da agência unindo-se a uma ideia de heteronomia (ou de uma "heteronomia sem servidão", como dirá Vladimir Safatle em artigo fruto da sua aula magna, em 2019).

Derrida já havia nos alertado de que o peso de uma metafísica centrada no 'próprio' pela proximidade a si da presença e de todos os conceitos que implicam o valor de "próprio" e "autêntico" em Ser e Tempo impôs-se no momento em que toda a preocupação ética foi suspensa (DERRIDA, 1991b, 101). Por sua vez, Safatle afirma no artigo citado que quando eu tomo distância do que me toca fora do meu domínio e experimento o que "eu" significa para além de sua realidade puramente psicológica, é, decerto nas condições históricas atuais sob o regime da propriedade, quando eu me torno sujeito autônomo, ajo, afirmo e desfruto orgulhoso de uma liberdade moral; ele diz, "raros foram os momentos nos quais tal crítica foi feita em nome da possibilidade de circulação do que é impróprio, do que não é configurado como propriedade, [o que] demonstra como boa parte de nosso esforço crítico permaneceu no mesmo horizonte normativo que fundamenta o que gostaríamos de criticar" (SAFATLE, 2019, 30).

Tal crítica chegaria a seu termo indesconstrutível se ascendermos ao que Levinas faz tocar como que em uma ferida, ou uma experiência ética que parte não do "eu" autônomo senão daquele que excede o meu domínio. Diz-se daquele outro que faz interromper a minha liberdade e para o qual respondo antes que consinto. Tratar-se-ia de um outro movimento do kratos político se me deparo, antes do auto nomos, com o hetero nomos cuja ideia não circunda o domínio do que me é próprio senão uma ideia de infinito e de "fora" - ideia cartesiana para aquilo que excede o domínio do "próprio" e que contrasta até mesmo com uma democracia que tem sido até agora a defesa inconteste da pessoa como proprietária de si. Da ideia cartesiana de infinito presente na ética do outro em Levinas, é que Derrida fará a desconstrução mediante o alter ego com que Husserl resolve a questão da comunidade; não sem deixar a marca de uma heteronomia que volta sempre a nutrir-se do infinito, como um espectro que assombra esse outro movimento pelo qual me movo a partir de fora, do inesperado, do choque de uma alteridade profunda que me interrompe na minha propriedade e na minha ipseidade.

Relação ao rosto do outro homem, dirá Levinas. Relação com o rosto, na medida em que eu próprio não sou rosto algum, que não me auto interrompo, mas insiro-me numa relação que é "relação sem relação" já que descumpre a ordem de uma simetria que partisse da autonomia de um sujeito moral em direção a uma outra autonomia de igual medida, que fosse em nome de uma universalidade. Relação ao outro que é, antes e ao invés de uma liberdade consentida, deferência a ele (a tu, que me faz face, e a eleidade, esse outro radical) cuja significância se 
deva exatamente a uma dissimetria, ou assimetria absoluta. Trata-se, assim, de uma ordem e de uma metafísica vindas de fora, de uma exterioridade não calculável mas precisa pela relação dissimétrica que convida e impera em seu favor, e heterônoma desde a sua pessoa.

A possibilidade de uma ética heterônoma (heterológica, para usarmos um termo de Derrida) se deve ao fato inaugural do dizer que me ensina o rosto e por ele decido. E a decisão, como resposta a ele, não constitui um imperativo tampouco uma inclinação. Não é da ordem de uma lei moral universal nem da ordem de uma afecção com que o dever se me apresenta à ordem da justiça. Este outro território - o do apelo - é a novidade de uma ética que se volta à lei dada pelo outro e que não está centrada na autodeterminação de um "eu" nem na determinação dos impulsos que o atravessam, mas é nesse apelo sem referência que uma ética se abre e inaugura um campo que passa a largo da ontologia e a uma distância cuidadosa da política, como veremos.

Este lugar aberto pela ética pensada por Levinas será onde a desconstrução se moverá em sulcamentos resistentes desde a escritura de Derrida. É talvez aqui que a escritura responda à justiça por uma lei maior em que o outro resista à pura identificação com a diferença. A ética em Levinas é, segundo Derrida, a ética da ética; sem lei, sem conceito, sem o fundamento de uma subjetividade ou de um humanismo que dela fosse extensão, mas é a "ética da ética" o seguimento de uma origem incerta (uma arqui-origem) no eixo da relação do homem ao homem. (Ressaltando aí, nesta relação entre homens, todas as reservas de que tomarão os leitores do pensamento de Levinas em torno do 'rosto', e que ademais ele procurará responder pelo lugar do feminino como lugar de acolhimento, e que com Derrida, que "soube reconhecer e respeitar a radical diferença do outro [de modo tal] que o próprio pensamento fosse contaminado por isso que é inteiramente outro" (HADDOCK-LOBO, 2008, 150), tomará outros contornos, especialmente pelo animal presente-ausente, rastro, na incisiva instância da ética.)

Trata-se, pois, de uma ética antes da ética, uma ética pré-ética e prépolítica e pré-social, pois trata-se de uma ética olhada desde fora das filosofias da subjetividade. O face-a-face assimétrico é sem máxima universalizável e é anterior à política, ao fenômeno e à própria ética normativa. "A ética é a filosofia primeira": eis o enunciado levinasiano levado a inúmeros mal entendidos. Pois, não se trata de uma anterioridade ou de uma primogenitura que tem a ética sobre a política, sobre o direito ou sobre a ontologia; mas, é o gesto mais resistente de uma desconstrução do lugar do 'sujeito moral' que descreve precisamente a operação do pensamento de Levinas. 
A partir de então, desse arqui-lugar ético do rosto que se abre à assimetria de uma relação a seu favor, todo ethos outro que não o que vem da filosofia levinasiana pareceria frágil, pouco convincente ou pouco ético, o que nos faria perguntar "o que seria uma ética sem o outro?". E a pergunta se dirige tanto a uma "ética das virtudes" que parece fixar-se no que Foucault atentará e irá recuperar mais tarde como uma "estética da existência" pelo cuidado de si rumo ao 'bem viver', quanto à ética dos contratos e dos imperativos da razão em nome de uma paz universal sempre regulada pela guerra entre os homens, ou ainda a um utilitarismo que apaga o rosto no corpo da maioria. O que é determinante na ética a partir de Levinas é o que Ihes faltou tomar à ordem desse dizer, mesmo aquilo que faltou ao Dasein ver de dentro do horizonte da morte uma outra "origem", ou melhor, o determinante à filosofia no instante do rosto, no instante em que o outro me atinge e me vale à decisão impossível que nunca lograrei recuperar em uma qualidade, numa escolha ou por uma adesão.

E acaso seria o carrasco, aquele que ameaça o meu próximo, também um rosto? Assim escreve Derrida sobre Levinas quanto a uma decisão que também receba o carrasco. "(...) salvar da morte um assassino assombrado pelo retorno espectral da vítima, perseguido pela revanche do fantasma, pelos vingadores decididos a matá-lo por sua vez. Daí sua extrema ambiguidade: é um culpado involuntário que é preciso albergar, é a um assassino que é preciso ainda conceder imunidade, uma imunidade ao menos provisória" (DERRIDA, 2004c, 131). Ainda encerrada no face-a-face que instaura a ética, disse Levinas, só posteriormente, a "violência do Estado", no cumprimento contratual da lei, ditará ao agressor do meu próximo a obra da justiça; quando então, sem rosto, for apreendido por um predicado: assassino. Segundo Levinas, só a justiça propiciará o diálogo na "contemporaneidade do múltiplo", representado pelo poder de direito que lhe concederá um novo rosto.

Há sempre uma ameaça e um equívoco que assombram a figura do "outro do meu outro" na filosofia levinasiana: a ameaça de ser interrompido o duelo do face-a-face na sua pureza ética; e o equívoco da própria ética em ter que escutar duas vozes e decidir por elas e dentre elas, que sejam, o grito dos "terceiros" que fazem seguir o direito e a política, de um lado, e, de outro lado, o face-a-face dado à intriga ética que, daquela maneira, seria esvaziado por sua concorrência estendida e dispersa.

Há, em Levinas, como que uma concorrência da justiça em dois sentidos distintos, numa dupla direção: se por um lado, "a relação com outrem é a justiça", assim está escrito em Totalidade e Infinito, ou ainda, nessa mesma obra, se a justiça é a "retidão do acolhimento feito a outrem" equacionando 
explicitamente a justiça à própria ética, por outro lado, e frente à necessidade de concretude e efetividade do dever moral à ordem do direito, estará o "outro do meu outro" a recolocar a ética ao alcance da política. Nesse sentido, a justiça será, então, a decisão que escapa à proximidade do rosto para atender a uma heteronomia radical ou a todos os diferentes do Outro, aos outros do meu outro, ou ainda o absolutamente outro membro de uma comunidade.

Uma democracia por vir, de uma comunidade heterônoma, seria aquela em que o estatuto fundamental de membro não se confundisse com o estatuto de proprietário e, portanto, da posse do possível e do próprio autônomo do qual as leis submetessem os demais membros, desde um cálculo até servidão. No modo de pensar de Safatle, o que seguimos nessa conclusão, nenhuma reconstituição da biopolítica que nos governa pode se realizar sem começar pela destituição da centralidade das relações de propriedade na definição da vida social, ética e política que nos cabe; o que interfere na própria noção do que entendemos por "sujeito" e por "possível". Pois, sujeitos teriam as marcas dos objetos que thes afetam e que eles portam, e as leis as marcas dos sujeitos que os submetem. Uma emergência de novos sujeitos políticos, dirá Safatle, é inseparável da emergência de um sujeito descentrado, e sujeitos descentrados pelo que aparece a eles como involuntário, contingente e opaco, que, então, é imediatamente apoderado como um objeto. A desconstrução como justiça, ou desde uma incondicionalidade de justiça à aparição do outro absoluto e de uma heteronomia tão estranha a nossa sensibilidade atual que só saberia ver nisto uma ferida narcísica, permite, ao contrário, uma operação generalizada de descentramento em que ser "humano" é, na verdade, estar constantemente fora de si.

\section{Bibliografia}

BADLEH, Jalal. De Derrida à Lévinas, la dette et l'envoi. Paris : L'Harmattan, 2015. BERNARDO, Fernanda. "Levinas e Derrida. 'Um contato no coração de um quiasma'". Revista Filosófica de Coimbra, n. 33 (2008) p. 39-78.

BERNARDO, Fernanda \& BENSUSSAN, Gérard. Os Equívocos da Ética/Les Équivoques de l'Éthique. A propósito dos /A propos des Carnets de Captivité de Levinas. Porto: FEAA, 2013.

CAPUTO, John. "Por amor às coisas mesmas: o hiper-realismo de Derrida", in DUQUE-ESTRADA, Paulo César (org.) Às Margens: a propósito de Derrida. São Paulo: Loyola, 2002, p. 29-48.

CRITCHLEY, Simon. The Ethics of Deconstruction, Derrida and Levinas. Edinburgh University Press, 1999.

DERRIDA, Jacques. Limited Inc. Campinas: Papirus, 1991(a). [Limited Inc. Paris, Galilée, 1990]

DERRIDA, Jacques. Margens da filosofia. Campinas : Papirus, 1991(b). [Marges de la philosophie. Paris : Editions de Minuit, 1972]

DERRIDA, Jacques. Force de loi. Paris: Galilée, 1994. [Trad. Bras. Força de lei. São Paulo : Martins Fontes, 2007] 
DERRIDA, Jacques. Cosmopolites de tous pays, encore un effort! Paris: Galilée, 1997.

DERRIDA, Jacques. Psyché : Inventions de l'autre II. Paris : Galilée, 2003(a).

DERRIDA, Jacques. Voyous: deux essais sur la raison. Paris: Galilée, 2003(b). [Trad. Port. Fernanda Bernardo, Vadios. Coimbra: Palimage, 2009]

DERRIDA, Jacques. \& ROUDINESCO, Elisabeth. De quoi demain... Dialogue. Paris : Flammarion, 2003(c). [Trad. Bras. De que amanhã... Rio de Janeiro: Zahar, 2004]

DERRIDA, Jacques. Pardonner: l'impardonnable et l'imprescriptible. Paris : Cahier de I'Herne, 2004(a).

DERRIDA, Jacques. "Como se fosse possível, "within such limits"..." in PapelMáquina. São Paulo: Estação Liberdade, 2004(b). [Papier-Machine. Paris : Galilée, 2001]

DERRIDA, Jacques. Adeus a Emmanuel Lévinas. São Paulo, Perspectiva, 2004(c). [Adieu à Emmanuel Lévinas. Paris, Galilée, 1997]

DERRIDA, Jacques. Séminaire La bête et le souverain, vol. 1: 2001-2002. Paris: Galilée, 2008.

DERRIDA, Jacques. "Violência e Metafísica: ensaio sobre o pensamento de Emmanuel Levinas" in A Escritura e a Diferença. São Paulo: Perspectiva, 2011. [L'écriture et la différence. Paris : Éditions du Seuil, 1967]

DUQUE-ESTRADA, Paulo César. "sobretudo... o perdão - (im)possibilidade, alteridade, afirmação", in DUQUE-ESTRADA, Paulo César (org.). Espectros de Derrida. Rio de Janeiro: Nau e PUC/Rio, 2008, p. 13-38.

HADDOCK-LOBO, Rafael. "Percursos do outro: ontologia, ética e desconstrução"; in DUQUE-ESTRADA, Paulo César (org.). Espectros de Derrida. Rio de Janeiro: NAU Ed., Ed. PUC-Rio, 2008, p. 121-154.

LEVINAS, Emmanuel. Totalité et Infini. Essai sur l'extériorité. Kluwer Academic (Nijhoff, 1971). [Trad. port. por José Pinto Ribeiro. Totalidade e Infinito. Lisboa: Ed. 70, 2000]

ROGOZINSKI, Jacob. Faire Part. Cryptes de Derrida. Paris: Éditions Lignes \& Manifestes, 2005.

SAFATLE, Vladimir. Crítica da autonomia: liberdade como heteronomia sem servidão. Revista Discurso, USP, v. 49, n. 2 (2019), pp. 21-41. 